\section{Occurrence of macrofungi on the Coromandel coast of Tamil Nadu, southern India}

\author{
S. Mani ${ }^{1} \&$ V. Kumaresan ${ }^{2}$ \\ ${ }^{1}$ Pitchandikulam Bioresource Centre, Auroville, Tamil Nadu 605101, \\ India \\ ${ }^{2}$ Department of Plant Science, Tagore Arts College, Puducherry \\ 605008, India \\ Email: ${ }^{1}$ manitrees@yahoo.com; ${ }^{2}$ vkumaresan36@yahoo.com
}

\section{Introduction}

Fungi are key functional components of forest ecosystems (Brown et al. 2006) and they have received less attention than animals and plants, although they are omnipresent and highly diverse in nature (Piepenbring 2007). Many macrofungal species are believed to fruit sporadically, with no consistent pattern of occurrence from year to year (Watling 1995). Moreover, their sporocarps are ephemeral and even when produced, may last only a few days before decomposing or being eaten (Brown et al. 2006). Having a stable and accepted estimate of taxonomic diversity for fungi is also necessary to enable fungi to be included in considerations of biodiversity conservation, land-use planning and management (Mueller \& Schmit 2007). In southern India, taxonomy of agarics has been carried out in the Western Ghats region (Natarajan et al. $2005 \mathrm{a}, \mathrm{b})$, but so far there are no reports on the study of macrofungal diversity in tropical dry evergreen forests. Thus, the aim of this study was to generate a baseline data on macrofungal diversity in the tropical dry evergreen forests on the Coromandel Coast of peninsular India.

\section{Materials and Methods}

The present study was conducted in one man-made forest and two naturally occurring forests. All the sites were within $25 \mathrm{~km}$ and were located on the Coromandel Coast of Tamil Nadu, southern India. The man made Pitchandikulam Forest (PF) $\left(11^{\circ} 59^{\prime} \mathrm{N} \& 79^{\circ} 49^{\prime} \mathrm{E}\right)$ is a well protected in 30ha of land having restored mixed forest. Reforestation programmes began

Date of online publication 26 January 2009

ISSN $0974-7907$ (online) | 0974-7893 (print)

Editor: V.B. Hosagoudar

Manuscript details:

Manuscript \# 01773; Received 03 May 2007; Final revised received 23 July 2008; Finally accepted 02 August 2008

Citation: Mani, S. \& V. Kumaresan (2009). Occurrence of macrofungi on the Coromandel coast of Tamil Nadu, southern India. Journal of Threatened Taxa 1(1): 54-57.

Copyright: (c) S. Mani \& V. Kumaresan 2009. Creative Commons Attribution 3.0 Unported License. JoTT allows unrestricted use of this article in any medium for non-profit purposes, reproduction and distribution by providing adequate credit to the authors and the source of publication.

Acknowledgements: We wish to dedicate this manuscript to our late Prof. K. Natarajan for his outstanding contribution to Indian Mycology.

OPEN ACGESS | FREE DOWNLOAD in 1973 by planting exotics, Acacia auriculiformis and Eucalyptus globulus and later there has been a significant shift in priority for restoring the indigenous tropical dry evergreen forest species (Ramanujam \& Anbarasan 2007).

The other two sites Oorani $(\mathrm{OR})\left(12^{\circ} 11^{\prime} \mathrm{N} \& 79^{\circ} 57^{\prime} \mathrm{E}, 1.5 \mathrm{ha}\right)$ and Puthupet (PP) $\left(12^{\circ} \mathrm{O} 3^{\prime} \mathrm{N} \& 79^{\circ} 52^{\prime} \mathrm{E}, 12 \mathrm{ha}\right)$ are naturally occurring in this part and are described as tropical dry evergreen forests (Champion \& Seth 1968). These sites are two to three layered forests occurring in drier areas, that experience about 3-6 dry months in a year, tree boles are mostly 8-12m in height, harbor largely evergreen species with a few deciduous and brevi-deciduous species and also a considerable number of lianas. It is mainly composed of Pterospermum canescens, Diospyros ebenum, Drypetes sepiaria, Garcinia spicata, Lepisanthes tetraphylla, Memecylon umbellatum and Eugenia bracteata (Venkateswaran \& Parthasarathy 2003; Parthasarathy \& Karthikeyan 1997). These sites occur presently in the form of 'temple forests' or 'sacred groves' and are disturbed by temple visitors. However, the Oorani site is comparatively less disturbed.

The present study was carried out during the rainy season between October 2006 - January 2007, the most favourable season for fruit body production. Macrofungal fruit bodies were collected once in a week from all the three sites. In the cases where fungi were not identified up to the species level, numbers were given to differentiate species belonging to the same genera after the study.

\section{Results and Discussion}

A total of 39 species of macrofungi, belonging to 25 genera in 17 families were recorded in the three study sites (Table 1). Twenty-eight species were enumerated in site PF, 20 species in site OR and 16 species in site PP. The species richness was high in site $\mathrm{PF}$ as the areal extent is more when compared to other two sites. Of the 39 species, 9 species (23\%) including Agaricus sp.1, Coprinus sp.1, Ganoderma lucidum, Gymnopilus sp., Marasmius sp.1, Marasmius sp. 2, Stereum sp., Termitomyces sp.1 and Xylaria sp. 1 were common to all the three sites (Table 2). This could be due to the fact that all the three sites have similar vegetation type influencing the macrofungal species composition; it is known that vegetation type influences the fungal species composition (Runge 1964). However, 23 species were unique to any one of the sites showing some degree of specificity for the sites (Table 2). But, a caveat needs to be added here since the sites compared are not of equal area and the number of sampling times is limited. Straatsma et al. (2001) monitored a plot area of $1500 \mathrm{~m}^{2}$ in western Switzerland for agarics for over a period of 21 -years with sampling frequency of 7 days and recorded 408 species but concluded that the number of species would increase if the survey continued.

The species occurring on different substrates varied considerably across the sites (Table 1). Most of the macrofungal species were recorded from soil (50.8\%), whereas only $9.5 \%$ of the species occurred in litter. This poor representation of litter fungi could be due to a more open canopy of the forests consequently leading to higher light levels, higher temperature and lower humidity. These environmental differences may have contributed to low sporocarp production 


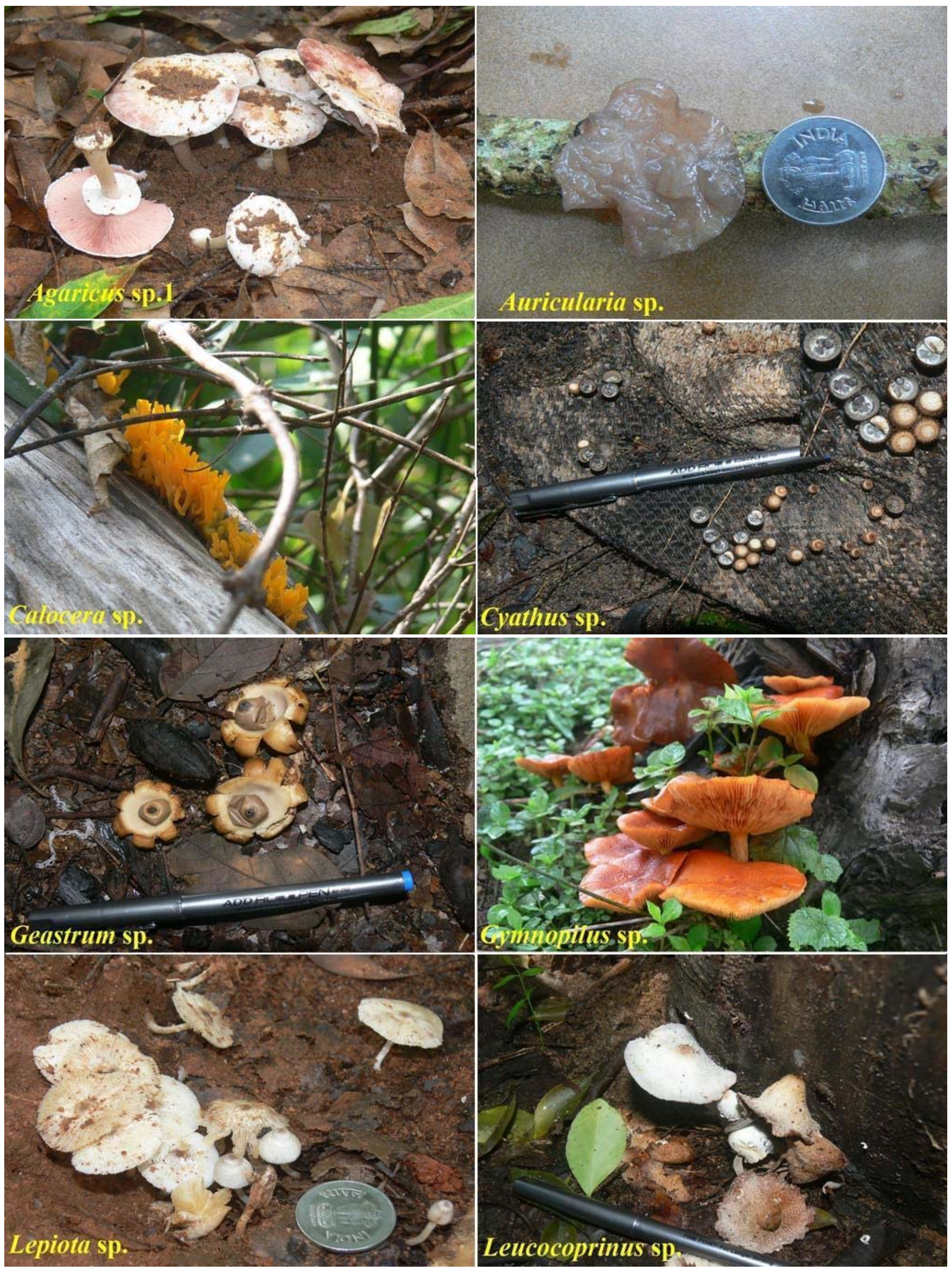




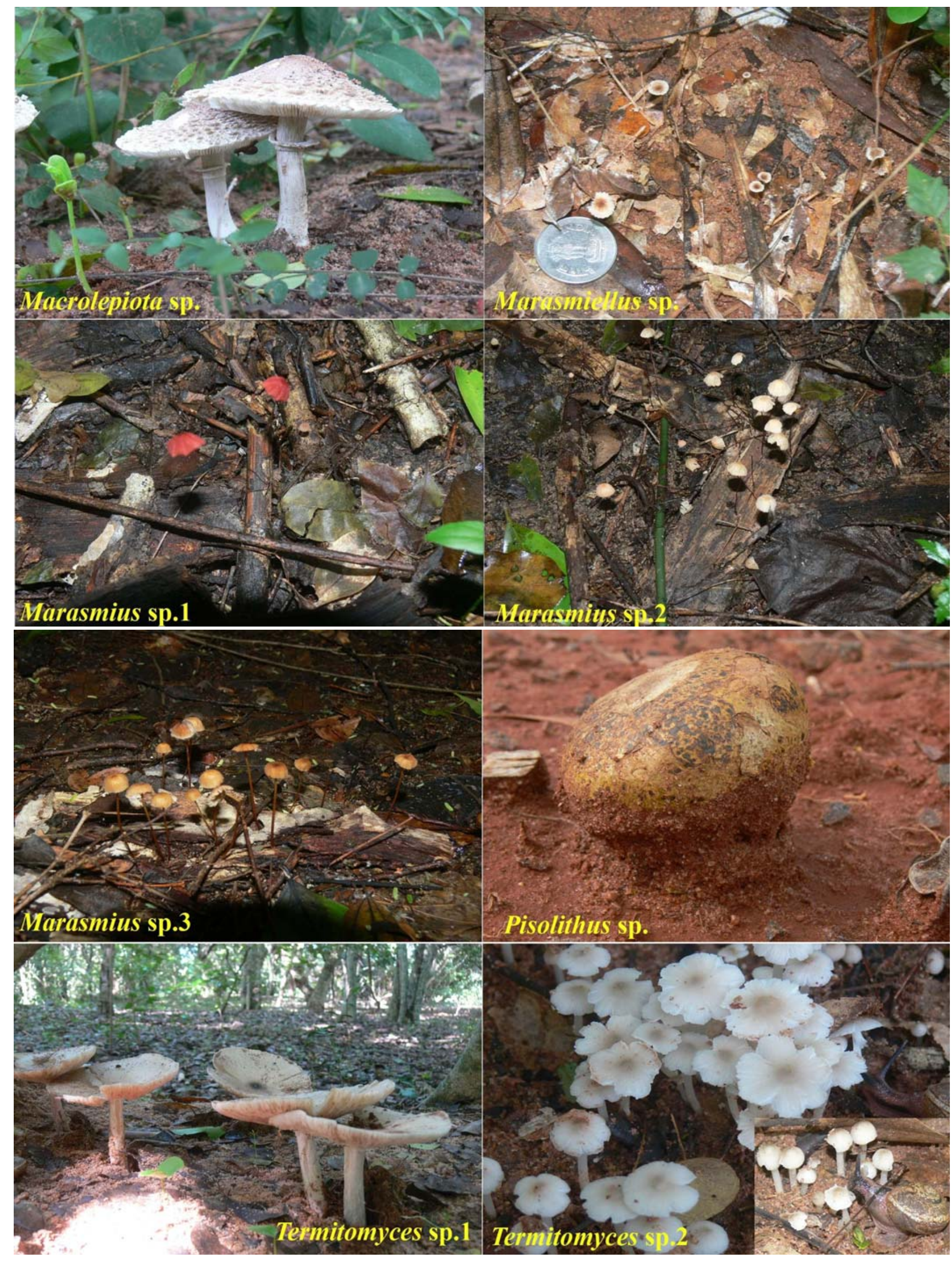




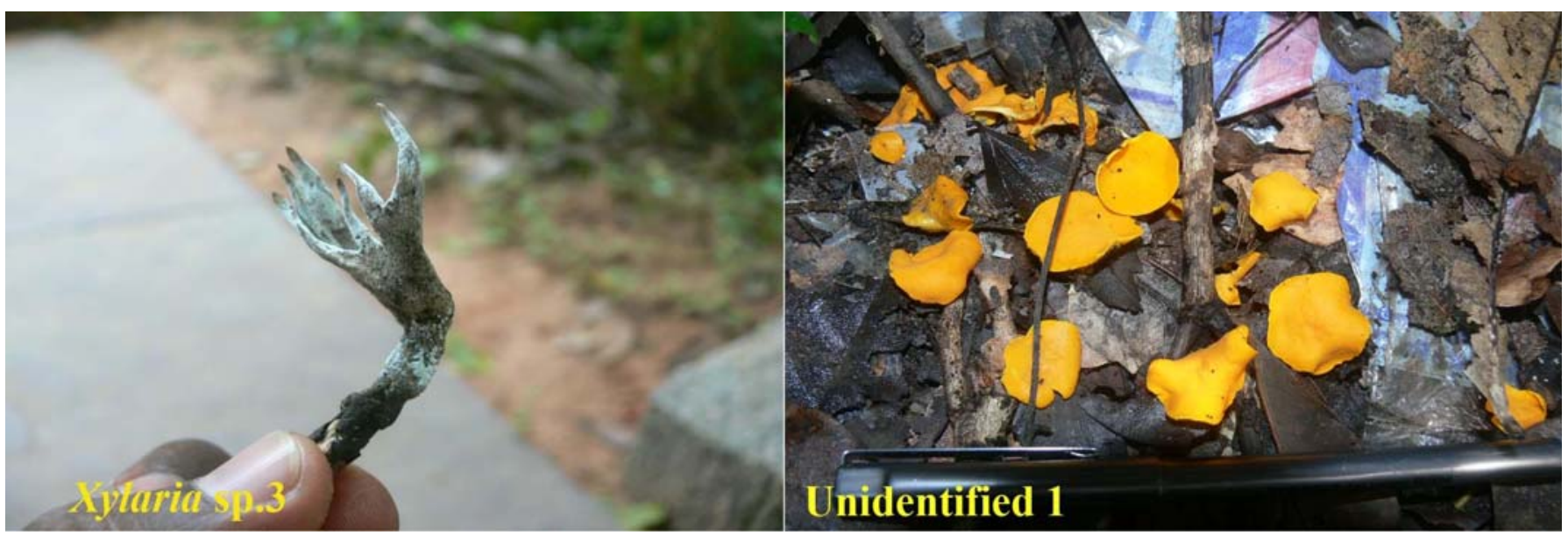

Table 1. Occurrence of macrofungi in the three tropical forest sites (PF - Pitchandikulam Forest, PP - Puthupet, OR Oorani) on the Coromandel Coast of southern India

\begin{tabular}{|c|c|c|c|c|}
\hline Variables & PF & $\begin{array}{l}\text { Site } \\
\text { OR }\end{array}$ & PP & $\begin{array}{l}\text { Total for } \\
\text { three sites }\end{array}$ \\
\hline Species richness & 28 & 20 & 16 & 39 \\
\hline Genera & 23 & 13 & 13 & 26 \\
\hline Family & 15 & 10 & 12 & 17 \\
\hline \multicolumn{5}{|l|}{ Substratum } \\
\hline Dead wood & 8 & 3 & 3 & 14 \\
\hline Dead twig & 5 & 3 & 3 & 11 \\
\hline Leaf litter & 3 & 1 & 2 & 6 \\
\hline Soil & 12 & 13 & 7 & 32 \\
\hline
\end{tabular}

(Brown et al. 2006). This baseline survey provides useful information on the occurrence and distribution of macrofungal species, particularly in the tropical dry evergreen forests.

\section{References}

Brown, N., S. Bhagwat \& S. Watkinson (2006). Macrofungal diversity in fragmented and disturbed forests of the Western Ghats of India. Journal of Applied Ecology 43(1): 11-17.

Champion, H.G. \& S.K. Seth (1968). A Revised Survey of the Forest Types of India. Manager of Publications, New Delhi, 404pp.

Mueller, G.M. \& J.P. Schmit (2007). Fungal biodiversity: what do we know? what can we predict? Biodiversity and Conservation 16(1): 1-5.

Natarajan, K., V. Kumaresan \& K. Narayanan (2005a). A check list of Indian agarics and boletes (1984-2002). Kavaka 33: 61-128.

Natarajan, K., K. Narayanan, C. Ravindran \& V. Kumaresan (2005b). Biodiversity of agarics from Nilgiri Biosphere Reserve, Western Ghats, India. Current Science 88(12): 1890-1892.

Parthasarathy, N. \& R. Karthikeyan (1997). Plant biodiversity inventory and conservation of two tropical dry evergreen forests on the Coromandel Coast, south India. Biodiversity and Conservation 6(8): 1063-1083.

Piepenbring, M. (2007). Inventoring the fungi of Panama. Biodiversity and Conservation 16(1): 73-84.

Ramanujam, M.E. \& R. Anbarasan (2007). A preliminary report on the vertebrate diversity of the Kaliveli watershed region. Zoos' Print Journal 22(3): 2608-2616.

Runge, F. (1964). Pflanzengesellschaften als Pilzstandorte. Zeitschrift fuer Pilzkunde 30: 14-2 1 .

Straatsma, G., F. Ayer \& S. Egli (2001). Species richness, abundance, and phenology of fungal fruit bodies over 21 years in a Swiss forest plot. Mycological Research 105(5): 515-523.

Venkateswaran, R. \& N. Parthasarathy (2003). Tropical dry evergreen forests on the Coromandel Coast of India: structure, composition and human disturbance. Ecotropica 9: 45-58.

Watling, R. (1995). Assessment of fungal diversity: macromycetes, the problems. Canadian Journal of Botany 73(1): 15-24.
Table 2. List of macrofungi enumerated in the three forest sites of Tamil Nadu, southern India

\begin{tabular}{|c|c|c|c|c|c|}
\hline SNo & Species name & Substratum & PF & OR & PP \\
\hline 1 & Agaricus sp.1 (Agaricaceae) & Soil & * & * & * \\
\hline 2 & Agaricus sp.2 (Agaricaceae) & Soil & - & * & - \\
\hline 3 & Agaricus sp.3 (Agaricaceae) & Soil & - & * & - \\
\hline 4 & Agaricus sp.4 (Agaricaceae) & Soil & - & * & - \\
\hline 5 & Auricularia sp. (Auriculariaceae) & Dead twig & * & - & * \\
\hline 6 & Calocera sp. (Dacrymycetaceae) & Dead wood & * & * & - \\
\hline 7 & Camarophyllus sp. (Hygrophoraceae) & Dead wood & * & - & * \\
\hline 8 & Coprinus sp.1 (Coprinaceae) & Soil & * & * & * \\
\hline 9 & Coprinus sp.2 (Coprinaceae) & Soil & - & * & - \\
\hline 10 & Cyathus sp. (Nidulariaceae) & Jute sac & - & - & * \\
\hline \multirow[t]{2}{*}{11} & Cystoagaricus trisulphuratus (Berk.) & & & & \\
\hline & Singer (Agaricaceae) & Soil & * & * & - \\
\hline \multirow[t]{2}{*}{12} & Daldinia concentrica (Bolton) Ces. \& & & & & \\
\hline & De Not. (Xylariaceae) & Dead wood & * & - & - \\
\hline 13 & $\begin{array}{l}\text { Ganoderma lucidum (Curtis) P. Karst. } \\
\text { (Ganodermataceae) }\end{array}$ & Dead wood & * & * & * \\
\hline 14 & Geastrum sp. (Geastraceae) & Soil & - & - & * \\
\hline 15 & Gerronema sp. (Tricholomataceae) & Dead twig & * & - & - \\
\hline 16 & Gymnopilus sp. (Cortinariaceae) & Dead wood & * & * & * \\
\hline 17 & Lepiota sp. (Agaricaceae) & Soil & * & * & - \\
\hline 18 & Leucocoprinus sp. (Agaricaceae) & Soil & - & * & - \\
\hline 19 & Lycoperdon sp. (Lycoperdaceae) & Soil & * & * & - \\
\hline 20 & Macrolepiota sp. (Agaricaceae) & Soil & * & - & * \\
\hline \multirow[t]{2}{*}{21} & Marasmiellus nigripes (Schwein.) & & & & \\
\hline & Singer (Tricholomataceae) & Leaf litter & * & - & - \\
\hline 22 & Marasmiellus sp. (Tricholomataceae) & Leaf litter & * & - & - \\
\hline 23 & Marasmius sp.1 (Tricholomataceae) & Leaf litter & * & * & * \\
\hline 24 & Marasmius sp.2 (Tricholomataceae) & Dead twig & * & * & * \\
\hline 25 & Marasmius sp.3 (Tricholomataceae) & Dead twig & - & * & - \\
\hline 26 & Micropsalliota sp. (Agaricaceae) & Soil & * & - & - \\
\hline 27 & Mycenasp. (Tricholomataceae) & Dead twig & * & - & - \\
\hline 28 & Pisolithus sp. (Sclerodermataceae) & Soil & * & - & - \\
\hline 29 & Ramaria sp.1 (Gomphaceae) & Soil & * & - & - \\
\hline 30 & Ramaria sp.2 (Gomphaceae) & Dead wood & * & - & - \\
\hline \multirow[t]{2}{*}{31} & Schizophyllum commune Fr. & & & & \\
\hline & (Schizophyllaceae) & Dead wood & * & - & - \\
\hline 32 & Stereum sp. (Stereaceae) & Dead twig & * & * & * \\
\hline 33 & Termitomyces sp.1 (Amanitaceae) & Soil & * & * & * \\
\hline 34 & Termitomyces sp.2 (Amanitaceae) & Soil & * & - & - \\
\hline 35 & Xylaria sp.1 (Xylariaceae) & Soil & * & * & * \\
\hline 36 & Xylaria sp.2 (Xylariaceae) & Soil & - & - & * \\
\hline 37 & Xylaria sp.3 (Xylariaceae) & Soil & - & * & - \\
\hline 38 & Unidentified 1 & Leaf litter & - & - & * \\
\hline 39 & Unidentified 2 & Dead wood & * & - & - \\
\hline
\end{tabular}

PF - Pitchandikulam Forest; OR - Oorani; PP - Puthupet; * - present, - absent 